\title{
廃プラの炭材としての利用技術
}

服部 正 $^{*}$

\section{Recycling Technique of Waste Plastics as Carbon Material}

\author{
Tadashi Hattori
}

\section{Synopsis}

Disposal of waste plastics amounts to about 10 million-t every year and 3 million-t of them are occupied to fill land and one of the causes to extinct space in Japan. As far, waste plastics have been applied to rotary kiln for cement manufacturing and fuel of blast furnace and coke oven as typical use. On the other side, use of carbon materials has been also developed on decrease of electric power consumption and oxygen blowing operation in an electric arc furnace.

In this paper, a recycling technique has been developed to utilize waste plastics as one of carbon materials for an electric furnace, and the effectiveness was examined by using a mass-production furnace. Results obtained are as follows.

1) Reduction of electric power consumption

Reduction of electric power consumption comparable with coke can be confirmed.

2) The increase of [C] in melting steel

A several percent increase by carbon containing plastics is confirmed.

\section{1.緒言}

廃プラは廃プラスチック類という項目に分類される廃

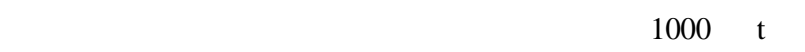

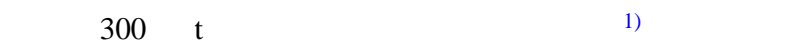
処分場枯渴の一因となっている.筆者らは，このうち毎年 約 200 万 $\mathrm{t}$ 埋立て処分されている産業廃棄物系の廃プラに 注目し,プラスチック中に含まれる炭素分を電炉の炭材と して有効にリサイクルするための技術開発を進めている． 廃プラを電炉用炭材として利用する場合 ,中間処分場で 破砕処理されたものを兴のまま電炉内に装入すると, 廃プ ラが高温の電炉内で急激に燃焼し周辺装置を損傷させる ため, 操業上問題がある . 乥こで, 廃プラの燃焼持続時間 を伸長させるとともに乥の嵩張りを軽減するため, 廃プラ を減容固化する技術を開発した .また，実炉を用いて電炉 溶解試験を行うことにより，減容固化物か熱源または加炭 剂としてどの程度有効であるかの確認を行ったので，关の 内容を報告する ．

\section{2 . 開発したプロセスの概要}

今回開発したプロセスを Fig.1 に示す . 原料の廃プラは 鉄粉と混合された後, ロータリーキルンで加熱される.こ れにより廃プラと鉄粉との造粒体 (溶融物) が得られる. 得られた造粒体は固形化プレスを用いて緻密化され，電炉 投入用の減溶固化物となる このプロセスについて以下に 種々の検討を行った結果を示す．

\section{3 . 廃プラの固形化技術}

\section{1 固化物の成形サイズの決定と緩慢燃焼}

固化物の成形サイズは, 電炉内での固化物の燃え切り時 間を卓上実験装置で得られた知見から外挿することによ り決定した .

亀嶋ら 2) は, 鉄とプラスチックを $1: 1$ の割合で混合さ せた固化物を用いて，1273 K の大気熱流下にある環状炉 内で $\varphi \quad 10 \sim \varphi 50$ までの小型固化物の燃焼による反応速 度を測定し，(1)式で示される実験式を得ている。 
$\ln v \fallingdotseq 1.497 \ln A+\ln 8.882 \times 10^{-6}$

ここで, $\mathrm{v}(1 / \mathrm{s})$ は反応速度, $\mathrm{A}\left(\mathrm{mm}^{2} / \mathrm{g}\right)$ はエリアインデッ クスと名付けられた量であり，(2) 式で表される .

$\mathrm{A}=\left(\text { 非接触表面積 }\left(\mathrm{mm}^{2}\right) \times \text { 接触表面積 }\left(\mathrm{mm}^{2}\right)\right)^{0.5}$

$$
\text { /重量 }(\mathrm{g})
$$

(2) 式において接触表面積は熱流が固化物に直接接触する 面の面積, 非接触面積は全表面積から接触面の面積を差し 引いた面積である .

いまここで, 固化物の形状が一辺 $200 \mathrm{~mm}$ の立方体であ るとすると, 全表面は $240000 \mathrm{~mm}^{2}$, 下面の面積 (非接触 表面積) は $40000 \mathrm{~mm}^{2}$ であり，また重量は約 $10000 \mathrm{~g}$ とお くと, $\mathrm{A}=(40000 \times 200000)^{0.5} / 10000 \fallingdotseq 8.94$ と求められ る.よって，v=2.36 $\mathrm{v} 10^{-4}$ となり, 反応速度の逆数が 反応時間であるので，反応時間は約 $4200 \mathrm{~s}$ と求められる． したがって，一辺が $200 \mathrm{~mm}$ の立方体固化物は，燃焼時間 が約 70 分であることが予想され，一般的な電炉のほぼ 1 チャージの溶解時間に相当することから，固化物の標準成
形サイズとして採用した .

\section{2 固化物に混装する鉄粉の選定}

電炉工場では鉄スクラップを搬送・装入する際にリフ ティングマグネット (以降リフマグと略) と呼ばれる大型 の電磁石が用いられている.廃プラと鉄からなる固化物は 鉄スクラップ中に混装して使用するため，鉄粉はリフマグ による搬送を可能にする働きを持つことが望まれる この 条件をみたす鉄粉はいくつか考えられるが，ここでは，定 期的にまとまった量が排出され，安定的に入手できること と，組成が比較的安定しており試験データを得るのに適し ているという観点から自動車工場などから排出される乾 式の加工ダライを選定した .

\section{3 廃プラの減容固化方法}

廃プラを加熱軟化させ, 鉄粉との造粒体 (溶融物) を形 成させるため, ロータリーキルンを用いて処理を行った . Table 1 にロータリーキルンの主な仕樣を示す .

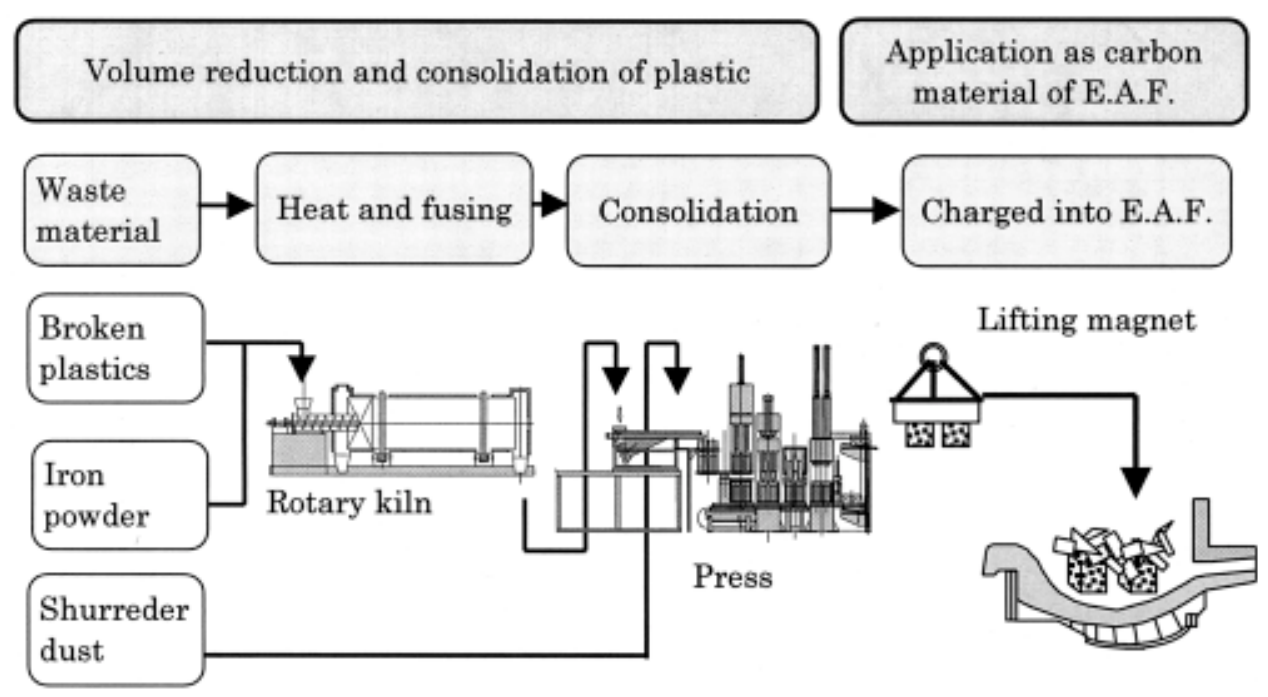

Fig.1. Schematic diagram of development process.

Table 1. Main specification of rotary kiln.

\begin{tabular}{|c|c|}
\hline Items & Specification \\
\hline Type of heating & $\begin{array}{l}\text { Direct heating from the opposite direction for product } \\
\text { (Re-heat system by exhaustion gas) }\end{array}$ \\
\hline Size & $\begin{array}{l}\text { Diameter } \varphi 1350 \times \text { length } 4800 \mathrm{~mm} \\
(\text { Lifting bar height } \times \text { pcs. } 110 \mathrm{H} \times 8 \text { ) }\end{array}$ \\
\hline Slope of kiln & $1 / 100(1 / 100 \sim 3 / 100$ variable $)$ \\
\hline Rotation per minutes & $\begin{array}{l}0.3 \mathrm{rpm} \sim 4 \mathrm{rpm}(3.2 \mathrm{rpm} \text { at } 60 \mathrm{~Hz}) \\
\text { Variable (by inverter) }\end{array}$ \\
\hline Heater & $\begin{array}{l}\text { Capacity : } 1293 \mathrm{Nm}^{3} / \mathrm{h} \text { max. temperature } 623 \mathrm{~K} \\
\text { Fuel : LNG }(13 \mathrm{~A}) \mathrm{max} \text {. consumption } 11.9 \mathrm{Nm}^{3} / \mathrm{h}\end{array}$ \\
\hline Circulation fan & $\begin{array}{l}\text { Type : Turbo fan (single suction type) } \\
\text { Capacity : } 30 \mathrm{~m}^{3} / \mathrm{h} \text { at } 450 \mathrm{mmAq} \text {. } \\
\text { Motor power : } 7.5 \mathrm{~kW}\end{array}$ \\
\hline
\end{tabular}




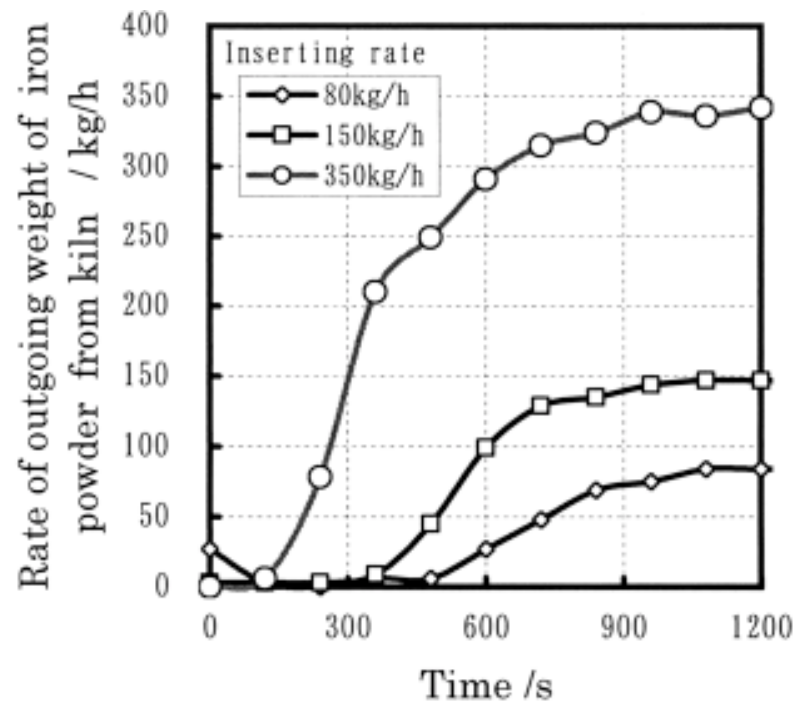

Fig.2. Variation of rate of outgoing weight of iron powder toward each inserting rate of weight.

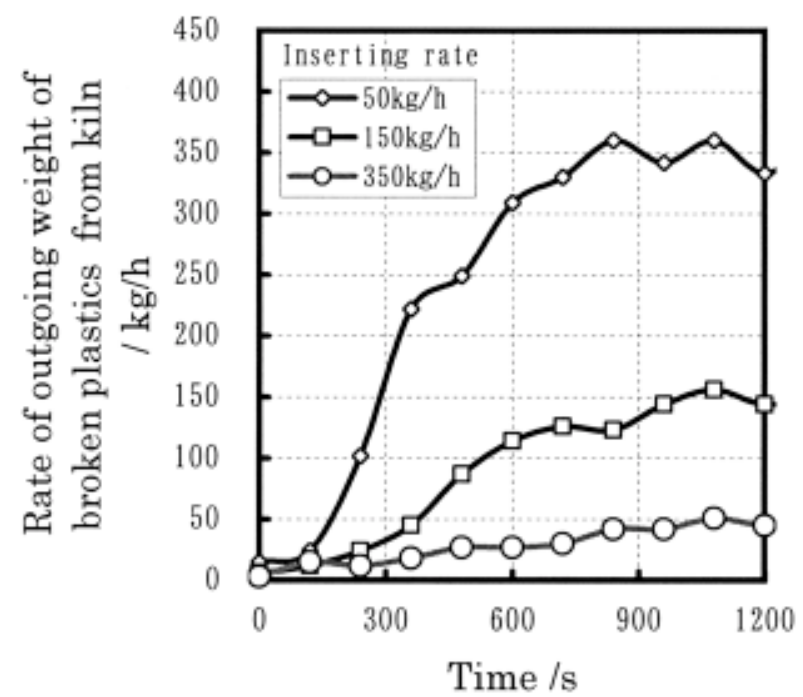

Fig.3. Variation of rate of outgoing weight of broken plastics toward each inserting rate of weight.
ロータリーキルンの最適運転条件を調査するために, 冷

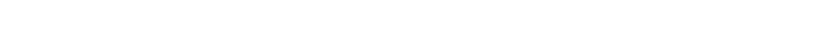
にロータリーキルンに装入し，装入から排出までの挙動を 調査した.なお，鉄粉は銑鉄ダライ (かさ密度 $2.0 \mathrm{~g} / \mathrm{cm}^{3}$ ) を使用した · また , ロータリーキルンの回転数は $4 \mathrm{rpm}$ と した . Fig.2 は鉄粉のロータリーキルンへの装入量と排出 量との関係を, Fig.3 は廃プラのロータリーキルンへの装

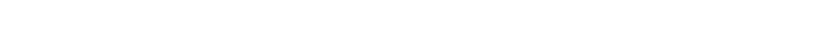
試験から，廃プラと鉄粉のように,かさ密度と形状のいず れもがたがいに大きく異なる材料であっても, 装入量と排 出量が等しくなる時間はほぼ等しく900秒程度という結果 が得られた .したがって, 鉄粉と廃プラはロータリーキル ン内では，均一に混合し搬送できることを確認できた .

つぎに,ロータリーキルンの熱精算を行うことにより熱 効率を調査した . Fig.4 にロータリーキルンの入熱・排熱 系統図を示す.熱精算は, 各箇所の温度および風量測定か ら，入熱量および排熱量を計算することにより実施した． ロータリーキルン炉内における熱収支から溶融効率が, バーナーにおける熱収支から排ガス利用効率が算出でき る. Table 2 は鉄粉として銑鉄ダライを, 廃プラとしてポ リプロピレン $(\mathrm{PP})$ および $\mathrm{ABS}$ を光れ光れ廃プラ : 鉄粉 $=$ 1:1で混装し, ロータリーキルンにて処理した場合の熱精 算結果である.ここで,廃プラ PP と廃プラ ABS は光れ光 れ 4:1 で配合している. Table 2 から, 排ガスの利用効率 を(3) 式で, 装入物への着熱効率を(4) 式で光れ光れ評価 すると, Table 3 の結果が得られた .

排ガスの利用効率 $=$ 循環ガス熱量

$$
\text { ノキルン炉内総入熱量 }
$$

装入物への着熱効率 $=$ 装入物の加熱に使用される熱量

$$
\text { ノキルン炉内総入熱量 }
$$

つぎに，固形化プレスによる成形条件を検討した．実験

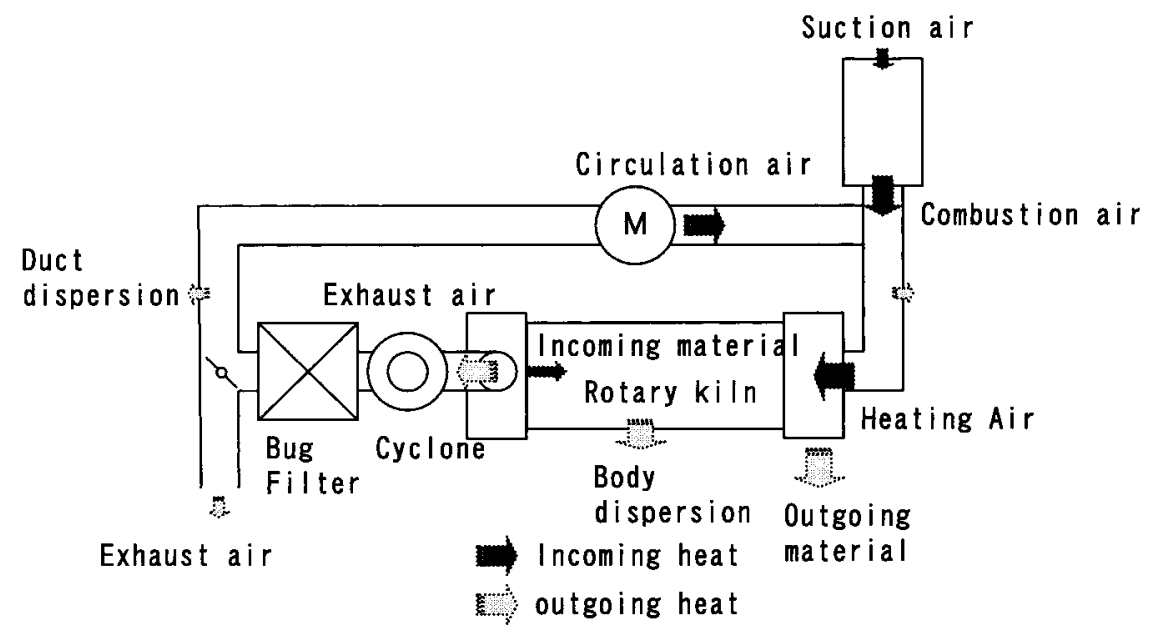

Fig.4. Thermal balance of rotary kiln. 
Table 2. Thermal balance of rotary kiln.

\begin{tabular}{|c|c|c|c|}
\hline \multirow{2}{*}{$\begin{array}{l}\text { Materials } \\
(\mathrm{kg} / \mathrm{h})\end{array}$} & \multicolumn{2}{|c|}{ Waste plastics } & 250 \\
\hline & \multicolumn{2}{|l|}{ Iron powder } & 250 \\
\hline \multicolumn{3}{|c|}{ Heating condition (Temperature, Air flow) } & $533 \mathrm{~K}, 750 \mathrm{Nm}^{3} / \mathrm{h}$ \\
\hline \multirow{8}{*}{$\begin{array}{l}\text { Thermal balance on } \\
\text { rotary kiln } \\
(\mathrm{kJ} / \mathrm{h})\end{array}$} & \multirow[t]{3}{*}{ Input } & Combustion air of burner & 14700 \\
\hline & & Materials & 1000 \\
\hline & & Input total & 15700 \\
\hline & \multirow[t]{5}{*}{ Output } & Heating of material & 5200 \\
\hline & & Exhaustion & 5700 \\
\hline & & Thermal dispersion from body & 1800 \\
\hline & & Thermal dispersion except body & 3000 \\
\hline & & Output total & 15700 \\
\hline \multirow{7}{*}{$\begin{array}{l}\text { Burner } \\
(\mathrm{kJ} / \mathrm{h})\end{array}$} & \multirow[t]{4}{*}{ Input } & Fuel Combustion & 11000 \\
\hline & & Circulation air & 3600 \\
\hline & & Suction air & 200 \\
\hline & & Input total & 14800 \\
\hline & \multirow[t]{3}{*}{ Output } & Combustion air & 14700 \\
\hline & & Thermal dispersion from piping & 100 \\
\hline & & Output total & 14800 \\
\hline
\end{tabular}

Table 3. Result for thermal efficiency of rotary kiln.

\begin{tabular}{l|l}
\hline Thermal recycling efficiency of exhaustion air (\%) & 23 \\
\hline Thermal efficiency of rotary kiln (\%) & 33 \\
\hline
\end{tabular}

Table 4. Main specification of press.

\begin{tabular}{l|l}
\hline Item & \multicolumn{1}{|c}{ Specification } \\
\hline Type & $\begin{array}{l}\text { Hydraulic press } \\
\text { (Max. load 20 t, Stroke } 675 \times \text { 4cylinder) }\end{array}$ \\
\hline Size & Length $10900 \times$ Width $4000 \times$ Height 5300 \\
\hline Standard mold & $\begin{array}{l}\text { Molding quantity per cycle : 4 (Array } 2 \times 2) \\
\text { Inner Size : 200 } \times 200 \times \text { depth 500 }\end{array}$ \\
\hline Capability & $500 \mathrm{~kg} / \mathrm{h}$ (mold water-cooling time : $60 \mathrm{~s})$ \\
\hline
\end{tabular}

に用いた固形化プレスの主な仕樣を Table 4 に示す . 金型 は 1 辺が $200 \mathrm{~mm}$ の正方形で, プロセスの進行方向に対し て 2 行 2 列の 4 個取りとなっている .このプレスを用いて 適正加圧条件を調査した . 廃プラとして, 破砕装置にて $50 \mathrm{~mm}$ アンダーで破砕された，ポリプロピレン (PP) およ び ABS を使用した．また，鉄粉としては銑鉄ダライを使 用した . 配合率は廃プラ PP : 廃プラ $\mathrm{ABS}:$ 鉄粉 $=4: 1: 5$ と した.

Fig.5 に4つの金型 (A〜D で図示) における加圧荷重 と製品高さの関係を示す.また，加圧荷重と製品の密度と の関係を Fig.6 に示す . Fig.5 および Fig.6 から荷重に対す る高さとの関係においてはバラツキか認められるが, 製品 の密度との関係においては,大きなバラツキはほとんど認 められなかった .つまり，プレス荷重は，金型あたり 9.8 $\times 10^{4} \mathrm{~N}$ 以上, 言い換えれば, $2.5 \mathrm{MPa}$ 程度の成形圧力が あれば均一な密度の固化物が成形できることが確認でき た。

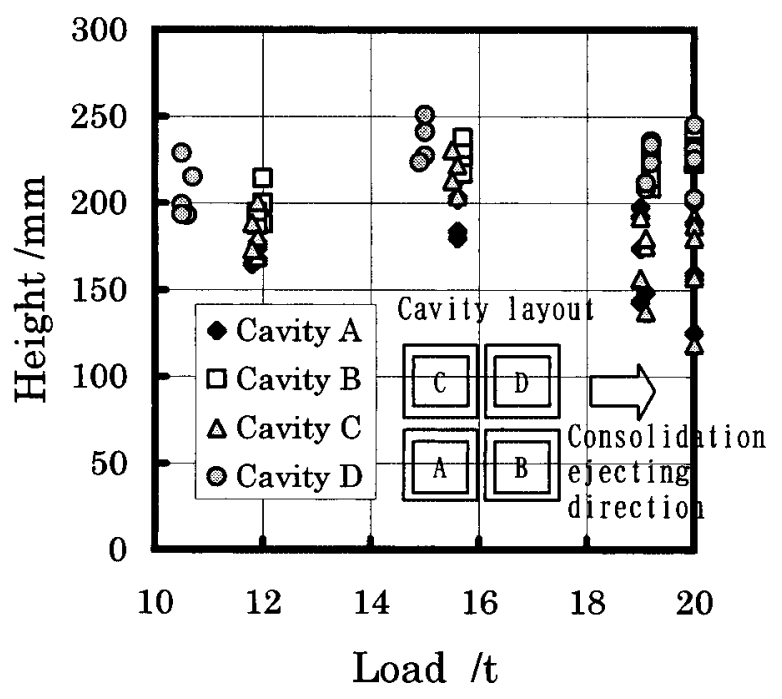

Fig.5. Relationship between load and height of solid. 


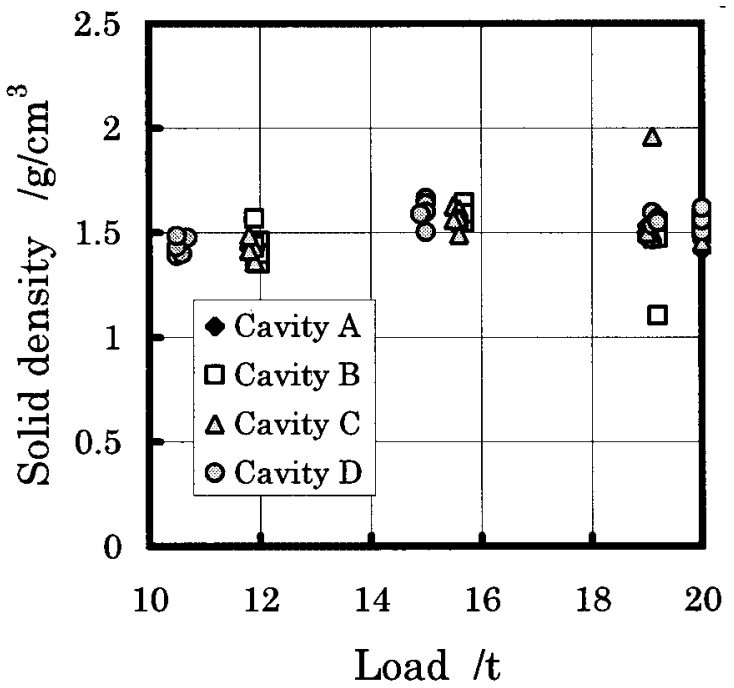

Fig.6. Relationship between load and solid density.

\section{4. 電炉における固化物溶解試験}

廃プラの構成物であるポリプロピレンは炭素 $85 \%$ から なる有機化合物である . 兴のため，廃プラを炭素 $85 \%$ の 炭材とみなし, 炭素当量で評価すれば, コークスや無煙炭 と同じ炭素源として取り扱えると考えられる，光こで, 廃 プラの炭材としての有効性を調査するために，実際に廃プ ラと鉄粉からなる固化物を電炉に装入し，溶解試験を実施 した.熱源としての有効性は着熱効率で, 加炭剂としての 有効性は加炭効率で評価した .ここで, 着熱効率とは炭材 の発熱量に対して, 電炉操業における電力原単位が減少し た割合にアークの着熱効率を掛けたものであり，(5) 式に て表される .

着熱効率 $\%=($ 炭材なし電力原単位 - 炭材装入時の 電力原単位 $) \times$ アーク効率 /炭材の発熱量

ここに示された電力原単位はスラグ酸化物組成による影 響や休転時間を考慮に入れた補正電力值である．

また加炭効率とは, 廃プラ中の炭素分に対する, 鉄スク ラップ溶け落ち直後の C 上昇割合をさす．

\section{1 試験方法}

電炉操業では, 鉄スクラップを 2 回または 3 回に分けて 装入し , 溶鋼を出鋼している.このうち, 初回に装入する スクラップの中に,先入れ炭材としてコークスや無煙炭を 装入し，熱源や加炭材として使用されている.固化物を炭 材として有効に使用するためには，電炉内の温度が比較的 低い初装で装入することが有利であり，周辺設備に悪影響 を与えないことにもなる .固化物は, 装入用バスケット内 の鉄スクラップの間にサンドイッチ状に装填し，電炉内へ

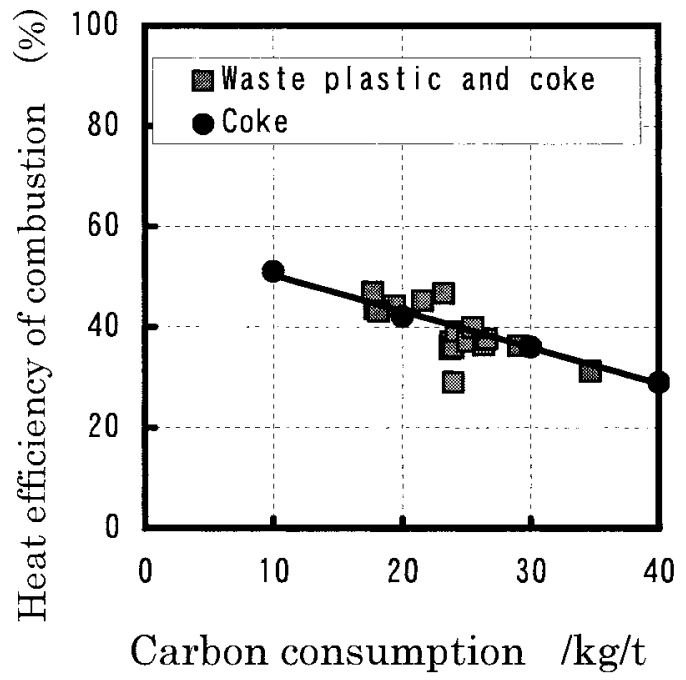

Fig.7. Relationship between carbon consumption and heat efficiency of combustion.

装入した .

\section{2 試験結果}

炭材装入量と着熱効率の関係を Fig.7 に示す . 図中には 炭材がコークスや無煙炭の場合の結果と, 固化物も含む場 合の結果が示されている . 炭材の発熱量は (6) 式のように 評価した。

$33.8 \mathrm{~kJ} / \mathrm{kg} \times 0.3+10.2 \mathrm{~kJ} / \mathrm{kg} \times 0.7=17.3 \mathrm{~kJ} / \mathrm{kg}$

ここで, カーボンの二次燃焼率の值は 0.3 とした . また， $33.8 \mathrm{~kJ} / \mathrm{kg}$ は, 炭材の完全燃焼時の発熱量, $10.2 \mathrm{~kJ} / \mathrm{kg}$ は不 完全燃焼時の発熱量である. Fig.7 から着熱効率は, 炭材 の溶解チャージあたりの装入重量が増えるにつれ減少す ることが認められた . また, 廃プラを添加したチャージは 炭材のみを装入して操業している実操業チャージと比べ てほぼ同じ挙動を示すことが認められた .

Fig.8 に廃プラの原単位と溶け落ち時 $[\mathrm{C}]$ 值の関係を示 す . [C] 值の評価にあたっては , 鉄スクラップからの [C] の寄与分は差し引いて評価した . 得られたデータから, 線 形回帰分析により, 固化物中のプラスチック $1 \mathrm{~kg} /$ 溶鋼 $\mathrm{t}$ に対し，[C] 值は $0.0032 \%$ 上がることが確かめられた .

これら一連の固化物溶解試験では, 無煙炭などの炭材添 加量は固化物を使用しない通常操業と同じ条件で使用し ているため, [C] 值の上昇分は光のまま, 固化物中の廃プ ラによる加炭効果であると考えられる.乥こで, この結果 を使用して廃プラ原単位で $10 \mathrm{~kg} /$ 溶鋼 $\mathrm{t}$ 装入した場合の 加炭効果を (7) 式のとおり試算した .ただし, 電炉の溶鋼 量を $\mathrm{A}(\mathrm{t})$ とする .

加炭効率 $(\%)=$ 実 $\mathrm{C}$ 歩留り量 $(\mathrm{kg})$ / 廃プラ中の C 量 $(\mathrm{kg})$ $\times 100$ ここで Fig.8 から，溶け落ちC 上昇分は $0.032 \%$ なので， 


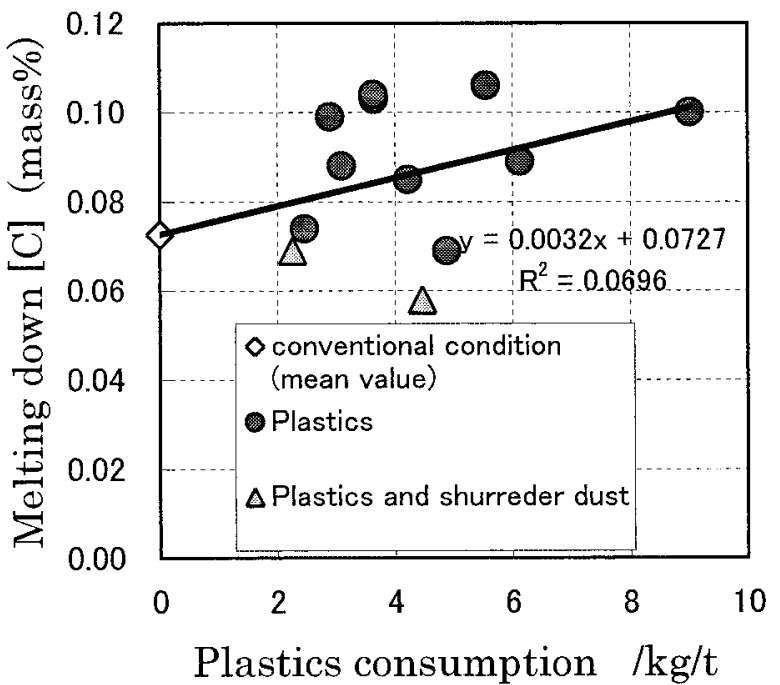

Fig.8. Relationship between plastic consumption and melting down [C].

実 $\mathrm{C}$ 歩留り量 $(\mathrm{kg})=$ 溶鋼量 $(\mathrm{t}) \times$ 溶け落ち $\mathrm{C}$ 上昇分

$$
\begin{aligned}
& =\mathrm{A} \times 1000 \times 0.032 \times 0.01 \\
& =0.32 \mathrm{~A} \mathrm{~kg}
\end{aligned}
$$

が得られる . 一方 , 廃プラ中の C 量は

廃プラ中の $\mathrm{C}$ 量 $(\mathrm{kg})=$ 溶鋼量 $(\mathrm{t}) \times$ 廃プラ投入量 $(\mathrm{kg} / \mathrm{t})$

$$
\begin{aligned}
& \times \text { 廃プラ中 } \mathrm{C} \text { 量 }(=85 \%) \\
& =\mathrm{A} \times 10 \times 0.85=8.5 \mathrm{~A} \mathrm{~kg}
\end{aligned}
$$

となる.よって, 廃プラの加炭効率は $0.32 \mathrm{~A} / 8.5 \mathrm{~A} \times 100$ $=3.8 \%$ となる.

\section{3 考察}

Fig.7 のデータを装入した全炭素中に占める廃プラ中の 炭素の割合で整理した .これを，Fig.9に示す.Fig.9から， 廃プラからの炭素分が占める割合か増加しても, 着熱効率 は廃プラ未使用の炭材のみの操業とほぼ同じレベルであ ることがわかる.すなわち，減容固化による廃プラは熱源 としてコークスや無煙炭などの炭材とほぼ同じ効果が認 められることが判明した .

一方, 加炭効果では, 廃プラ中の加炭効率は $3.8 \%$ に留 まった .この原因は, 一般鋼, 普通鋼の実操業では, 炭材 を加炭源よりもむしろ熱源として活用しているので, 大量 の酸素を溶綱に吹き込み,炭材は排ガス化してしまうため 溶綱中に留まり難くなるためと推定される .

$$
5 \text {. 結 論 }
$$

今回 , 廃プラと鉄粉を混装し, 固形化することで電炉の 熱源や加炭剂として一定の効果があることが確認できた . ただし，今回の電炉溶解試験では, 単純に既存の電炉操業 条件上に廃プラを追装した試験であり，有機物である廃プ

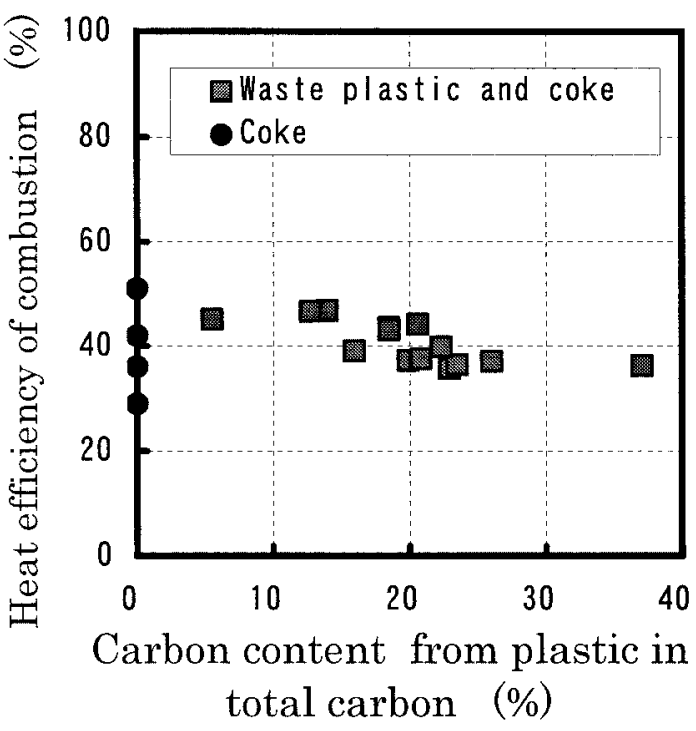

Fig.9. Relationship between carbon content from plastic and heat efficiency of combustion.

ラの利用条件としての最適化は図られていない .今後 , 電 炉排ガスの組成分析および熱精算を実施し，炭材としての 最適な利用条件を詰めていく必要がある.これにより，熱 源としての最適利用方法および加炭剂としての最適利用 方法について電炉操業条件の確立を目指す.また，廃プラ は炭素と水素からなる有機化合物であるため, 塩化物と結 びついて生成するダイオキシン類との関係を明らかにす ることも今後の課題として残されている .

\section{6 . 謝 辞}

本研究の一部は, 経済産業省および独立行政法人新エネ ルギー・産業技術総合開発機構 (NEDO 技術開発機構) の 助成をうけて実施したものである. 関係各位に感謝する .

(文 献)

1) プラスチック処理促進協会編: プラスチックリサイク ルの基礎知識 .

2) 亀嶋保 堀田雅也, 成瀬一郎, 大森浩志:製鋼用電炉にお ける熱源・炭素源としての廃プラスチックスの適応, 第 147回日本鉄鋼協会春季講演大会 ,大岡山 ,2004. 